[9] Kim, J., and Kim, Y., 2000, Layout planning for facilities with fixed shapes and input and output points; International Journal of Production Research, 38 (18), 46354653.

[10] Meller, R. D. and Gan, K. Y. - The facility layout problem; Recent and Emerging Trends and perspectives; Journal of Manufacturing systems, Vol. 5, 1996, pp. 351364.

[11] Moghaddain, R., and Shayan, E., 1998, Facility layout design by genetic algorithm, Computer and Industrial Engineering, 35 (3-4), 527 - 530.

[12] Rajasekharan, M., Peters, B.A.; Yang, T., 1998, A Genetic algorithm for facility layout design in flexible manufacturing system, International Journal of Production Research, 36, 95-110.

[13] Tam, K.Y., 1992a, A simulated annealing algorithm for allocating space to manufacturing cells, International Journal of Production Research, 30, 63 - 87.

[14] Tam, K.Y., 1992b, Genetic algorithms, function optimization and facility layout design, European Journal of Operation Research, 63, 322 - 346.

[15] Wang, T., and Peters, A., 1998, Flexible machine layout design for dynamic and uncertain production environment, European Journal of Operation Research, 108, 49 $-64$.

[16] Welgama, B., and Gibson, P.R., 1996, An integrated methodology for automating the determination of layout and material handling system, International Journal of Production Research, 34 (8), 2247-2264.

[17] Wu, Y., Appleton, E., 2002, Integrated design of block layout and aisle structure by simulated annealing, International Journal of Production Research, 40 (10), 23532365.

\title{
ATTENTION
}

\section{Members of ORSI}

The Central Council of Operational Research Society of India, during the meeting held on 20 March, 2004 opined that the directory of members of the Society should include the e-mail id of the respective member, so that the headquarters can maintain quick communication with them.

The members are requested to intimate their e-mail id to the headquarters through orsihq@cal2.vsnl.net.in 